\title{
Ibotenic Acid Analogues. Synthesis and Biological Testing of Two Bicyclic 3-Isoxazolol Amino Acids
}

\author{
Ulf Madsen, Kjeld Schaumburg ${ }^{a}$, Lotte Brehm, David R. Curtis ${ }^{b}$ and Povl \\ Krogsgaard-Larsen
}

Department of Chemistry BC, Royal Danish School of Pharmacy, 2, Universitetsparken, DK-2100 Copenhagen

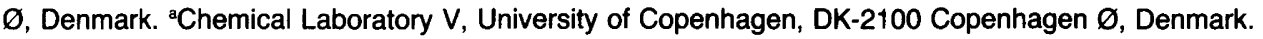
'Department of Pharmacology, The Australian National University, Canberra, A.C.T. 2601, Australia

\begin{abstract}
Madsen, Ulf, Schaumburg, Kjeld, Brehm, Lotte, Curtis, David R. and Krogsgaard-Larsen, Povl*, 1986. Ibotenic Acid Analogues. Synthesis and Biological Testing of Two Bicyclic 3-Isoxazolol Amino Acids. - Acta Chem. Scand. B 40: 92-97.

The bicyclic 3-isoxazolol amino acids (RS)-3-hydroxy-4,5,6,7-tetrahydroisoxazolo[4,5-c]pyridine-4-carboxylic acid (5, 4-HPCA) and ( $R S)$-3-hydroxy4,5,6,7-tetrahydroisoxazolo[4,5-c]pyridine-6-carboxylic acid (11,6-HPCA) were synthesized as model compounds for studies of the structural requirements of central excitatory amino acid neurotransmitter receptors. 4-HPCA was synthesized $v i a$ introduction of a methoxycarbonyl group into the 4-position of the lithiated $N$ nitroso intermediate 1 . The key reaction in the synthesis of 6-HPCA is an intramolecular $\mathrm{N}$-alkylation of the appropriately substituted acetamidomalonate derivative 7 using sodium hydride as a base. On the basis of the $\mathrm{p} K_{\mathrm{A}}$ values for 4HPCA the existence of an intramolecular hydrogen bond in the zwitterionic form of this amino acid is proposed. 6-HPCA was shown by ${ }^{1} \mathrm{H}$ NMR spectroscopy to adopt preferentially a conformation with the carboxylate group in an equatorial position. 4- and 6-HPCA were tested as agonists and antagonists at excitatory amino acid receptors on neurones in the cat spinal cord using microelectrophoretic techniques. Neither compound showed significant effects at these receptors.
\end{abstract}

Accumulating evidence strongly suggests that the amino acids $(S)$-glutamic acid (GLU) and $(S)$-aspartic acid (ASP) are the major excitatory neurotransmitters in the mammalian central nervous system. ${ }^{1-3}$ The possible involvement of these amino acid transmitters in certain neurological diseases ${ }^{4,5}$ has focused much interest on the central excitant amino acid receptors as sites for pharmacological and therapeutic attack. Electrophysiological and receptor binding studies have disclosed heterogeneity of these receptors, which at present are most conveniently subdivided into three classes: $:^{6-9}$ (1) Quisqualic acid (QUIS) receptors, at which the naturally occurring amino acid QUIS is a selective agonist; (2) $N$-methyl- $(R)$-aspartic acid (NMA) receptors, at which NMA is a powerful agonist and a number of com-

*To whom correspondence should be addressed.

92 Acta Chemica Scandinavica B 40 (1986) 92-97 pounds, including 2-aminoadipic acid, are antagonists (Scheme 1); (3) kainic acid receptors.

The QUIS receptors probably represent the postsynaptic GLU receptors..$^{10}$ Using the naturally occurring amino acid ibotenic acid as a lead structure, structure-activity studies on a number of specific QUIS receptor agonists such as AMPA $^{11}$ and 5-HPCA ${ }^{12}$ (Scheme 1), have shed light on the "receptor-active conformation" of GLU at these receptors.

The NMA receptors are assumed to represent primarily central ASP receptors. ${ }^{13}$ However, very little is known about the "receptor-active conformations" of ASP and NMA and the conformation, in which 2-aminoadipic acid binds to and blocks these receptors. As part of our current studies of these aspects we now report the synthesis of (RS)-3-hydroxy-4,5,6,7-tetrahydroisoxazolo[4,5-c]pyridine-4-carboxylic acid (5, 4HPCA) and (RS)-3-hydroxy-4,5,6,7-tetrahydro- 
isoxazolo[4,5-c]pyridine-6-carboxylic acid (11, 6HPCA), which are conformationally restricted analogues of NMA and 2-aminoadipic acid, respectively (Scheme 1).

\section{Results and discussion}

Since ibotenic acid is relatively easily decarboxylated,$^{14}$ and 4-HPCA in analogy to ibotenic acid has a carboxylate group in a position $\alpha$ to the isoxazole ring (Scheme 1), a reaction sequence for the synthesis of 4-HPCA (5) was developed, in which the carboxylate group was unmasked under mild conditions in the last step (Scheme 2). A methoxycarbonyl group was introduced regiospecifically into the 4-position of 1 under strongly basic conditions. Attempts to substitute other bases, including sodium hydride or potassium tert-butylate, for butyllithium failed to give detectable amounts of 2 . The stepwise deprotection of 2 was initiated by passing a stream of hydrogen bromide gas through a solution of 2 in glacial acetic acid, until the formation of a brown volatile product, assumed to be nitrosyl bromide, ceased. The 3-methoxy group of 3 was selectively cleaved by treatment of 3 with a concentrated solution of hydrogen bromide in glacial acetic acid, whereas the conversion of 4 into 5 was accomplished by treatment of 4 with an aqueous solution of triethylamine.

Treatment of 6 with equimolar amounts of $\mathrm{N}$-bromosuccinimide (NBS) gave 7 contaminated with very small amounts of the dibromo compound 8 . A separable mixture of 7 and 8 was obtained by using NBS in excess. Compound 8 is a key intermediate in the synthesis of other compounds related to ibotenic acid. Cyclization of 7 into 9 was accomplished using sodium hydride as a base. The reaction product obtained after demethylation of 10 using hydrogen bromide in glacial acetic acid gave after treatment with water the zwitterion 11 rather than its hydrobromide. This observation probably is the result of the exceptionally low $\mathrm{p} K_{\mathrm{A}}$ I value $(<1.2)$ of 11 .

The structures of the new compounds $2-5$ and 7-11 were established on the basis of elemental analyses, IR, and ${ }^{1} \mathrm{H}$ NMR spectroscopic data, and, in the case of 2 , by mass spectrometry. In agreement with the findings for $1,{ }^{15}$ two sets of resonance signals were detected in the ${ }^{1} \mathrm{H}$ NMR spectrum of 2 due to hindered rotation around the $\mathrm{N}-\mathrm{N}$ bond. A comparison of the $\mathrm{p} K_{\mathrm{A}}$ values of $5(1.6,5.8,8.5)$ with those of $11(<1.2,4.2$, 8.2), ibotenic acid $(3,5.0,8.2),{ }^{16}$ AMPA (2.5, $4.8,10.0)$, and 5-HPCA $(2.2,4.7,8.1)$ reveals a strikingly large difference between the $\mathrm{p} K_{\mathrm{A}} \mathrm{I}$ and II values of 5 . This difference is interpreted in terms of the existence of an intramolecular hydrogen bond ${ }^{17}$ between the carboxylate and hydroxy groups of 5 (Scheme 1). There is no obvious explanation of the exceptionally low $\mathrm{p} K_{\mathrm{A}} \mathrm{I}$ value of 11 .

The ${ }^{1} \mathrm{H}$ NMR spectrum of 11 shows coupling constants between the C-6 proton and the two C-7 protons $\left(J_{6 \mathrm{aza}}=10 \mathrm{~Hz}, J_{6 \mathrm{a} \mathrm{e}^{\prime}}=5 \mathrm{~Hz}\right)$ in accordance with axial-pseudoaxial and axial-pseudoequatorial configurations, respectively, of these protons. This is consistent with a predominantly equatorial orientation of the carboxylate group at C-6. Long-range couplings between the C-4 and C-7 protons $(J=0.5,2,2$, and $2 \mathrm{~Hz})$ were detected in the ${ }^{1} \mathrm{H}$ NMR spectrum of 11 .

The effects of 5 (4-HPCA) and 11 (6-HPCA) on cat spinal neurones were tested using microelectrophoretic techniques. ${ }^{18}$ However, neither 4nor 6-HPCA showed any significant excitatory effects on these neurones, and neither compound was capable of reducing significantly the excitatory effects of QUIS, NMA, or kainic acid. These observations seem to indicate that 4HPCA, designed as a conformationally restricted analogue of NMA (Scheme 1), does not reflect the active conformation of NMA at its receptors. Similarly, the inactivity of 6-HPCA has been interpreted in terms of 2-aminoadipic acid adopting a conformation different from that reflected by its conformationally restricted analogue 6-HPCA (Scheme 1) during its binding to and blockade of the NMA receptors.

\section{Experimental}

Melting points are corrected and were determined in capillary tubes. Elemental analyses were performed by Mr. P. Hansen, Chemical Laboratory II, University of Copenhagen. IR spectra, obtained on a Perkin-Elmer Grating Infrared Spectrophotometer, model 247, were recorded in $\mathrm{KBr}$ pellets. The $60 \mathrm{MHz}{ }^{1} \mathrm{H}$ NMR spectra (compounds 2-4 and 7-10) were recorded at $25^{\circ} \mathrm{C}$ on a Varian $360 \mathrm{~L}$ spectrometer. The 270 $\mathrm{MHz}$ spectra (compounds 5 and 11 ) were recorded on a Bruker HX $270 \mathrm{~S}$ instrument. Fourier transform method was used to obtain the 
spectra with spectral widths of 3000 or $5000 \mathrm{~Hz}$ with digital resolution of $0.3 \mathrm{~Hz}$. TMS was used as an internal standard except for the compounds dissolved in $\mathrm{D}_{2} \mathrm{O}$, where 3-(trimethylsilyl)propanesulphonate was used. Thin layer chromatography (TLC) and gravity column chromatography (CC) were performed using silica gel $F_{254}$ plates (Merck) and silica gel (Woelm, 0.063$0.200 \mathrm{~mm}$ ), respectively. Compounds containing the 3-isoxazolol unit were visualized on TLC plates using UV light and a $\mathrm{FeCl}_{3}$ spraying reagent (yellow colour). Compounds containing amino groups were visualized using a ninhydrin spraying reagent, and all compounds under study were detected on TLC plates using a $\mathrm{KMnO}_{4}$ spraying reagent. All evaporations were performed at $c a .15 \mathrm{~mm} \mathrm{Hg}$ using a rotatory evaporator. The $\mathrm{p} K_{\mathrm{A}}$ values were determined using a published procedure, ${ }^{19,20}$ except that the titration was carried out with $0.1 \mathrm{~N} \mathrm{HCl}$ or $0.1 \mathrm{~N} \mathrm{NaOH}$. The ionic strength was kept constant using 0.15 $\mathrm{M} \mathrm{KCl}$.

(RS)-Methyl 3-methoxy-5-nitroso-4,5,6,7-tetrahydroisoxazolo[4,5-c]pyridine-4-carboxylate (2). To a stirred solution of $1^{15}(1.00 \mathrm{~g} ; 5.5 \mathrm{mmol})$ in dry tetrahydrofuran (THF) $(20 \mathrm{ml})$, kept under a ni-

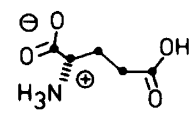

(S) -Glutamic acid (GLU)
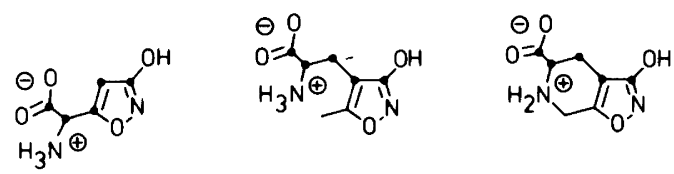

Ibotenic acid

A MPA

5-HPCA<smiles>N[C@@H](CC(=O)O)C(=O)[O-]</smiles><smiles>CN[C@@H](CC(=O)O)C(=O)[O-]</smiles>

(S)-Aspartic N-Me-( $\underline{R})$-Aspar acid tic acid (NMA)<smiles>N[C@@H](CCC(=O)O)C(=O)OCC(=O)O</smiles><smiles>O=C(O)C1(C(=O)O)CCC2ON=C(O)C21</smiles><smiles>O=C(O)C(O)(O)c1c(O)noc1CO</smiles>
$4-H P C A(\underline{5})$<smiles>O=C(O)[C@H]1Cc2c(O)noc2NC1=O</smiles>

Scheme 1.<smiles>CCOC(=O)C(Cc1onc(OC)c1C)(NC(C)=O)C(=O)OCC</smiles>

6 N B S<smiles>CCOC(=O)C(Cc1onc(OC)c1CBr)(NC(C)=O)C(=O)OCC</smiles>

7 $1 \mathrm{NaH}$<smiles>CCOC(=O)C1(C(=O)OCC)Cc2onc(OC)c2CN1CCO</smiles><smiles>COC(=O)C1c2c(OC)noc2CCN1N=O</smiles>

1

2<smiles>COC(=O)C1c2c(O)noc2CCN1C(=O)C(Br)(Br)Br</smiles><smiles>COc1noc2c1CNC(C(=O)O)C2</smiles>

10<smiles>O=C([O-])C1Cc2onc(O)c2C[NH2+]1</smiles>

11

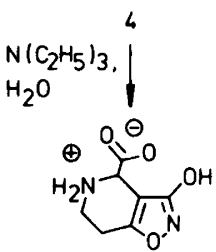

5

Scheme 2. 
trogen blanket at $c a .-75^{\circ} \mathrm{C}$, was added butyllithium ( $4.0 \mathrm{ml}$ of a $1.5 \mathrm{M}$ solution in hexane; 6.0 $\mathrm{mmol}$ ), and after $1 \mathrm{~min}$ methyl chloroformate $(4.2 \mathrm{ml} ; 55 \mathrm{mmol})$ was added during a period of 1 min. Stirring was continued at $c a .-75^{\circ} \mathrm{C}$ for 5 min, and upon addition of glacial acetic acid $(0.2$ $\mathrm{ml})$ the solution was evaporated. Water $(15 \mathrm{ml})$ was added to the residue and the mixture extracted with dichloromethane $(3 \times 20 \mathrm{ml})$. The combined and dried $\left(\mathrm{MgSO}_{4}\right)$ organic phases were evaporated. $\mathrm{CC}$ [silica gel: $100 \mathrm{~g}$; eluents: dichloromethane containing ethyl acetate (5$10 \%)$ ] gave $2(208 \mathrm{mg} ; 16 \%)$, m.p. $99.5-100.5^{\circ} \mathrm{C}$ (ethyl acetate-light petroleum). Anal. $\mathrm{C}_{9} \mathrm{H}_{11} \mathrm{~N}_{3} \mathrm{O}_{5}: \mathrm{C}, \mathrm{H}, \mathrm{N}$. IR: $3400(\mathrm{w}), 2995$ (w), 2960 (w), 2930 (w), 1745 (s), 1660 (m), 1525 (s) $\mathrm{cm}^{-1} .{ }^{1} \mathrm{H}$ NMR $\left(\mathrm{CDCl}_{3}\right): \delta 6.4(0.2 \mathrm{H}, \mathrm{s}), 6.2(0.8$ $\mathrm{H}, \mathrm{s}), 5.4-5.0(1 \mathrm{H}, \mathrm{m}), 4.7-4.2(1 \mathrm{H}, \mathrm{m}), 4.2(\mathrm{ca}$. $0.6 \mathrm{H}, \mathrm{s}), 4.1(\mathrm{ca} .2 .4 \mathrm{H}, \mathrm{s}), 3.9$ (ca. $0.6 \mathrm{H}, \mathrm{s}), 3.8$ (ca. 2.4 H, s), 3.3-2.8 (2 H, m). MS [70 eV; $m / z$ (\% rel. int.)]: 241 (7, M), 222 (6), 211 (39), 182 (100), 152 (73), 137 (31), 121 (25), 59 (29).

(RS)-Methyl 3-methoxy-4,5,6,7-tetrahydroisoxazolo[4,5-c]pyridine-4-carboxylate hydrobromide (3). Through a solution of $2(200 \mathrm{mg}$; $0.83 \mathrm{mmol})$ in glacial acetic acid $(10 \mathrm{ml})$, kept at $0^{\circ} \mathrm{C}$, was passed a stream of hydrogen bromide gas, until the solution became pale yellow $(60 \mathrm{~s})$. The solution was immediately evaporated and the residue recrystallized (methanol-ether) to give 3 (224 mg; $92 \%$ ), m.p. $143-144^{\circ} \mathrm{C}$ (decomp.). Anal. $\mathrm{C}_{9} \mathrm{H}_{13} \mathrm{~N}_{2} \mathrm{O}_{4} \mathrm{Br}: \mathrm{H}, \mathrm{N}, \mathrm{Br}$; C: Calcd, 36.88; found 36.00 . IR: $3600-3300(w), 3010-$ 2400 (several bands, m-s), 1745 (s), 1665 (s), $1545(\mathrm{~s}), 1525(\mathrm{~s}) \mathrm{cm}^{-1} .{ }^{1} \mathrm{H}$ NMR $\left(\mathrm{D}_{2} \mathrm{O}\right): \delta 5.5(1$ $\mathrm{H}, \mathrm{s}), 4.1(3 \mathrm{H}, \mathrm{s}), 4.0(3 \mathrm{H}, \mathrm{s}), 4.0-3.6(2 \mathrm{H}, \mathrm{m})$, 3.3-3.0 (2 H, m).

(RS)-Methyl 3-hydroxy-4,5,6,7-tetrahydroisoxazolo[4,5-c]pyridine-4-carboxylate Hydrobromide (4). A solution of $3(100 \mathrm{mg} ; 0.34 \mathrm{mmol})$ in a solution of hydrogen bromide in glacial acetic acid $(5 \mathrm{ml} ; 33 \%)$ was kept at $25^{\circ} \mathrm{C}$ for 18 h. The solution was evaporated and the residue recrystallized (methanol-ether) to give $4(85 \mathrm{mg}$; $89 \%$ ), m.p. $141-143^{\circ} \mathrm{C}$ (decomp.). Anal. $\mathrm{C}_{8} \mathrm{H}_{11} \mathrm{~N}_{2} \mathrm{O}_{4} \mathrm{Br}$. C, H, N, Br. IR: $3600-3300(w)$, 3200-2400 (several bands, w-m), 1750 (s), 1665 (m), 1565-1500 (several bands, $\mathrm{m}$ ) $\mathrm{cm}^{-1} .{ }^{1} \mathrm{H}$ NMR $\left(\mathrm{D}_{2} \mathrm{O}\right): \delta 5.5(1 \mathrm{H}, \mathrm{s}), 4.0(3 \mathrm{H}, \mathrm{s}), 4.0-3.6$ (2 H, m), 3.3-3.0 (2 H, m).
(RS)-3-Hydroxy-4,5,6,7-tetrahydroisoxazolo-

[4,5-c]pyridine-4-carboxylic Acid Zwitterion (4HPCA) (5). A solution of $4(200 \mathrm{mg} ; 0.72 \mathrm{mmol})$ and triethylamine $(1 \mathrm{ml})$ in water $(7 \mathrm{ml})$ was kept at $25^{\circ} \mathrm{C}$ for $3 \mathrm{~h}$ and then evaporated. The residue was dissolved in a mixture of water $(0.3 \mathrm{ml})$ and ethanol $(3 \mathrm{ml})$. Upon adjustment of $\mathrm{pH}$ of this solution to $c a$. 3 with glacial acetic acid crude 5 (122 $\mathrm{mg}$ ) precipitated. Recrystallization (water) gave $5(105 \mathrm{mg} ; 80 \%$, based on 4$)$, m.p. 202$204^{\circ} \mathrm{C}$ (decomp.). Anal. $\mathrm{C}_{7} \mathrm{H}_{8} \mathrm{~N}_{2} \mathrm{O}_{4}: \mathrm{H}, \mathrm{N}$; C: calcd, 45.66; found 45.03. IR: $3600-3300(\mathrm{~m})$, 3200-2300 (several bands, m), 1690 (s), 1660 (s), $1530(\mathrm{~s}), 1500(\mathrm{~s}) \mathrm{cm}^{-1} .{ }^{1} \mathrm{H}$ NMR $\left(\mathrm{D}_{2} \mathrm{O}\right): \delta 4.91(1$ $\mathrm{H}, \mathrm{s}), 3.75-3.65(1 \mathrm{H}, \mathrm{m}), 3.56-3.44(1 \mathrm{H}, \mathrm{m})$, 3.03-2.95 $(2 \mathrm{H}, \mathrm{m}) \cdot \mathrm{p} K_{\mathrm{A}}$ values $\left(\mathrm{H}_{2} \mathrm{O}, 25^{\circ} \mathrm{C}\right): 1.6$, $5.8,8.5$.

Ethyl $\alpha$-ethoxycarbonyl- $\alpha$-acetamido-3-methoxy4-bromomethylisoxazole-5-propionate (7) and Ethyl $\alpha$-ethoxycarbonyl- $\alpha$-acetamido-3-methoxy4-dibromomethylisoxazole-5-propionate

(8).

Method A. A solution of $6^{21}(550 \mathrm{mg} ; 1.6 \mathrm{mmol})$, NBS (a total of $286 \mathrm{mg} ; 1.6 \mathrm{mmol}$ ), and benzoylperoxide (a total of $10 \mathrm{mg}$ ) in THF $(10 \mathrm{ml})$ was refluxed for $4 \mathrm{~h}$. NBS and benzoylperoxide were added in quarter portions each hour. The mixture was filtered and evaporated to give a crystalline product. CC [silica gel: $100 \mathrm{~g}$; eluents: toluene containing ethyl acetate (5-11\%)] gave 7 $(487 \mathrm{mg} ; 72 \%)$ and $8(16 \mathrm{mg} ; 2 \%) .7:$ m.p. 81.0 $82.0^{\circ} \mathrm{C}$ (ethyl acetate-light petroleum). Anal. $\mathrm{C}_{15} \mathrm{H}_{21} \mathrm{~N}_{2} \mathrm{O}_{7} \mathrm{Br}: \mathrm{C}, \mathrm{H}, \mathrm{N}, \mathrm{Br}$. IR: $3290(\mathrm{~m}), 3030$ (w), $2980(\mathrm{~m}), 1750$ (s), 1650 (s) 1530 (s), 1510 (m) $\mathrm{cm}^{-1}$. ${ }^{1} \mathrm{H}$ NMR $\left(\mathrm{CDCl}_{3}\right): \delta 6.8(1 \mathrm{H}, \mathrm{s}), 4.3(4$ $\mathrm{H}, \mathrm{q}, J 7 \mathrm{~Hz}), 4.1(2 \mathrm{H}, \mathrm{s}), 4.0(3 \mathrm{H}, \mathrm{s}), 3.8(2 \mathrm{H}$, s), $2.0(3 \mathrm{H}, \mathrm{s}), 1.3((6 \mathrm{H}, \mathrm{t}, J 7 \mathrm{~Hz}) .8$ : m.p. 105.5-106.5 ${ }^{\circ} \mathrm{C}$ (ethyl acetate-light petroleum). Anal. $\mathrm{C}_{15} \mathrm{H}_{20} \mathrm{~N}_{2} \mathrm{O}_{7} \mathrm{Br}_{2}: \mathrm{C}, \mathrm{H}, \mathrm{N}$; Br: calcd, 31.95; found, 31.05. IR: $3220(\mathrm{~m}), 3010(\mathrm{w}), 2990(\mathrm{~m})$, 1745 (s), 1635 (s), 1535 (s) $\mathrm{cm}^{-1} .{ }^{1} \mathrm{H}$ NMR $\left(\mathrm{CDCl}_{3}\right): \delta 6.8(1 \mathrm{H}, \mathrm{s}), 6.4(1 \mathrm{H}, \mathrm{s}), 4.3(4 \mathrm{H}, \mathrm{q}, J$ $7 \mathrm{~Hz}), 4.1(3 \mathrm{H}, \mathrm{s}), 3.9(2 \mathrm{H}, \mathrm{s}), 2.1(3 \mathrm{H}, \mathrm{s}), 1.3$ $(6 \mathrm{H}, \mathrm{t}, J 7 \mathrm{~Hz})$. Method B. Compound $\sigma^{21}(550$ $\mathrm{mg} ; 1.6 \mathrm{mmol}$ ) was treated with NBS (a total of $429 \mathrm{mg} ; 2.4 \mathrm{mmol}$ ) and benzoylperoxide (a total of $10 \mathrm{mg}$ ) as described above (Method A). Obtained were $7(196 \mathrm{mg} ; 29 \%)$ and $8(109 \mathrm{mg}$; $26 \%)$.

Ethyl 3-methoxy-6-ethoxycarbonyl-5-acetyl4,5,6,7-tetrahydroisoxazolo[4,5-c]pyridine-6-car- 
boxylate (9). To a suspension of sodium hydride $(18.2 \mathrm{mg} ; 0.76 \mathrm{mmol})$ in dry $N, N$-dimethylformamide $(2.5 \mathrm{ml})$, kept at $\mathrm{ca} .-15^{\circ} \mathrm{C}$, was added, during a period of $30 \mathrm{~min}, 7(160 \mathrm{mg} ; 0.38 \mathrm{mmol})$. After stirring for an additional $30 \mathrm{~min}$ at $c a$. $-10^{\circ} \mathrm{C}$ glacial acetic acid $(0.2 \mathrm{ml})$ was added and the solution evaporated. Upon addition of water $(5 \mathrm{ml})$ the mixture was extracted with chloroform $(3 \times 10 \mathrm{ml})$. The combined chloroform phases were dried $\left(\mathrm{MgSO}_{4}\right)$ and evaporated to give an oil. CC [silica gel: $7 \mathrm{~g}$; eluents: dichloromethane containing butanone $(5-10 \%)]$ gave $9(84 \mathrm{mg}$; $65 \%$ ), m.p. $89.0-90.0^{\circ} \mathrm{C}$ (ethyl acetate-light petroleum). Anal. $\mathrm{C}_{15} \mathrm{H}_{20} \mathrm{~N}_{2} \mathrm{O}_{7}: \mathrm{C}, \mathrm{H}, \mathrm{N}$. IR: $3600-$ 3320 (w), 3020 (w), 2990 (m), 1745 (s), 1730 (s), 1690 (s), 1680 (s), 1530 (s) $\mathrm{cm}^{-1}$. ' $\mathrm{H}$ NMR $\left(\mathrm{CDCl}_{3}\right): \delta 4.5(2 \mathrm{H}, \mathrm{s}), 4.3(4 \mathrm{H}, \mathrm{q}, J 7 \mathrm{~Hz}), 4.0$ $(3 \mathrm{H}, \mathrm{s}), 3.5(2 \mathrm{H}, \mathrm{s}), 2.2(3 \mathrm{H}, \mathrm{s}), 1.3(6 \mathrm{H}, \mathrm{t}, J 7$ $\mathrm{Hz}$ ).

(RS)-3-Methoxy-4,5,6,7-tetrahydroisoxazolo14,5-c/pyridine-6-carboxylic acid hydrochloride (10). A suspension of $9(150 \mathrm{mg} ; 0.44 \mathrm{mmol})$ in hydrochloric acid $(10 \mathrm{ml} ; 1 \mathrm{M})$ was heated to reflux for $2.5 \mathrm{~h}$. After cooling to $25^{\circ} \mathrm{C}$ and filtration the solution was evaporated to dryness and the residue recrystallized (methanol-ethyl acetate) to give $10(57 \mathrm{mg} ; 55 \%)$, m.p. $220-224^{\circ} \mathrm{C}$ (decomp.). Anal. $\mathrm{C}_{8} \mathrm{H}_{11} \mathrm{~N}_{2} \mathrm{O}_{4} \mathrm{Cl}: \mathrm{C}, \mathrm{H}, \mathrm{N}$; $\mathrm{Cl}$ : calcd, 15.11; found, 12.92. IR: $3600-3300(w), 3200-$ 2300 (m-s), 1750 (s), $1675(\mathrm{~m}), 1570$ (w), 1520 (s) $\mathrm{cm}^{-1}$. ${ }^{1} \mathrm{H}$ NMR $\left(\mathrm{D}_{2} \mathrm{O}\right): \delta 4.4(1 \mathrm{H}, \mathrm{m}), 4.2(2 \mathrm{H}$, s), $3.9(3 \mathrm{H}, \mathrm{s}), 3.3(2 \mathrm{H}, \mathrm{m})$.

\section{(RS)-3-Hydroxy-4,5,6,7-tetrahydroisoxazolo}

[4,5-c]pyridine-6-carboxylic acid zwitterion. 1/4 $\mathrm{H}_{2} \mathrm{O}(6-\mathrm{HPCA})$ (11). A solution of $10(30 \mathrm{mg}$; $0.13 \mathrm{mmol}$ ) in a solution of hydrogen bromide in glacial acetic acid $(1.5 \mathrm{ml} ; 33 \%)$ was kept at $25^{\circ} \mathrm{C}$ for $18 \mathrm{~h}$ and then evaporated. The residue was dissolved in water $(15 \mathrm{ml})$ and the solution evaporated. Recrystallization (water) of the residue gave $11(18 \mathrm{mg} ; 75 \%)$, m.p. $>350^{\circ} \mathrm{C}$. Anal. $\mathrm{C}_{7} \mathrm{H}_{8} \mathrm{~N}_{2} \mathrm{O}_{4} \cdot 1 / 4 \mathrm{H}_{2} \mathrm{O}: \mathrm{C}, \mathrm{H}, \mathrm{N}$. IR: $3600-3300$ (m), 3115 (s), $2970(\mathrm{w}), 2840-2300$ (several bands, $\mathrm{w}-\mathrm{m}), 1670(\mathrm{~s}), 1650-1500$ (several bands, $\mathrm{m}-\mathrm{s}$ ) $\mathrm{cm}^{-1}$. ${ }^{1} \mathrm{H}$ NMR (sodium carbonate in $\mathrm{D}_{2} \mathrm{O}, c a .1$ M): $\delta 3.61(1 \mathrm{H}$, broad dd, $J 15,2$, and $0.5 \mathrm{~Hz})$, 3.49 (1 H, dt, $J 15,2$, and $2 \mathrm{~Hz}$ ), 3.47 (1 H, dd, $J$ 10 and $5 \mathrm{~Hz}), 2.83(1 \mathrm{H}$, broad dq, $J 16.5,5,2$, and $0.5 \mathrm{~Hz}), 2.57(1 \mathrm{H}$, ddt, $J 16.5,10,2$, and 2 $\mathrm{Hz})$. $\mathrm{p} K_{\mathrm{A}}$ values $\left(\mathrm{H}_{2} \mathrm{O}, 25^{\circ} \mathrm{C}\right):<1.2,4.2,8.2$. $p \mathrm{~K}_{A}$ Values for (RS)- $\alpha$-amino-3-hydroxy-5-methylisoxazole-4-propionic Acid (AMPA) and (RS)3-hydroxy-4,5,6,7-tetrahydroisoxazolo[5,4-c]pyridine-5-carboxylic acid (5-HPCA). AMPA $\left(\mathrm{H}_{2} \mathrm{O}, 25^{\circ} \mathrm{C}\right): 2.5,4.8,10.0$. 5-HPCA $\left(\mathrm{H}_{2} \mathrm{O}\right.$, $\left.25^{\circ} \mathrm{C}\right): 2.2,4.7,8.1$.

Microelectrophoretic studies. Experiments were performed on lumbar dorsal horn interneurones and Renshaw cells of cats anaesthetized with pentobarbitone sodium $(35 \mathrm{mg} / \mathrm{kg}$ intraperitoneally initially, supplemented intravenously when required). Extracellular action potentials were recorded by means of the centre barrel of seven-barrel micropipettes, which contained 3.6 $\mathrm{M} \mathrm{NaCl}$. The compounds were administered electrophoretically from the outer barrels of the micropipettes, ${ }^{18}$ which contained aqueous solutions: NMA (0.05 $\mathrm{M}$ in $0.15 \mathrm{M} \mathrm{NaCl}, \mathrm{pH} 7.6)$, QUIS $(0.005 \mathrm{M}$ in $0.15 \mathrm{M} \mathrm{NaCl}, \mathrm{pH} 7.5)$, 4HPCA (0.1 M, pH 7.3), and 6-HPCA (0.1 M, pH 7.3). The excitatory amino acids were administered for times sufficient to obtain maximal effects at the particular rate of ejection.

Acknowledgements. This work was supported by grants from The Danish Medical Research Council and The Danish Natural Sciences Research Council. The technical assistance of Mrs. P. Searle, Mr. J. S. Johansen, and Mr. S. Stilling and the secretarial assistance of Mrs. B. Hare are gratefully acknowledged.

\section{References}

1. Di Chiara, G. and Gessa, G. L., Eds., Glutamate as a Neurotransmitter, Raven, New York 1981.

2. Roberts, P.J., Johnston, G. A. R. and StormMathiesen, J., Eds., Glutamate: Transmitter in the Central Nervous System, John Wiley \& Sons, Chichester and New York 1981.

3. Hertz, L., Kvamme, E., McGeer, E.G. and Schousboe, A., Eds., Glutamine, Glutamate and GABA in the Central Nervous System, Alan R. Liss, New York 1983.

4. Coyle, J. T., Bird, S. J., Evans, R. H., Gulley, R. L., Nadler, J.V., Nicklas, W.J. and Olney, J.W. Neurosci. Res. Prog. Bull. 19 (1981) 333.

5. Watkins, J. C. and Evans, R. H. Annu. Rev. Pharmacol. Toxicol. 21 (1981) 165.

6. Davies, J. and Watkins, J. C. J. Physiol. (London) 297 (1979) 621. 
7. Peet, M. J., Leah, J. D. and Curtis, D. R. Brain Res. 266 (1983) 83.

8. McLennan, H. Prog. Neurobiol. 20 (1983) 251.

9. Foster, A. C. and Fagg, G. E. Brain Res. Rev. 7 (1984) 103.

10. Monaghan, D. T., Yao, D. and Cotman, C.W. Brain Res. 324 (1984) 160.

11. Krogsgaard-Larsen, P., Honoré, T., Hansen, J. J., Curtis, D. R. and Lodge, D. Nature (London) 284 (1980) 64.

12. Krogsgaard-Larsen, P., Brehm, L., Johansen, J. S., Vinzents, P., Lauridsen, J. and Curtis, D. R. J. Med. Chem. 28 (1985) 673.

13. Watkins, J. C. Trends Pharmacol. Sci. 5 (1984) 373.

14. Nielsen, E. Ø., Schousboe, A., Hansen, S. H. and Krogsgaard-Larsen, P. J. Neurochem. 45 (1985) 725.
15. Krogsgaard-Larsen, P., Johansen, J. S. and Falch, E. J. Labelled Compd. 19 (1982) 689.

16. Eugster, C. H. Fortschr. Chem. Org. Naturst. 27 (1969) 261.

17. Eberson, L. In Patai, S., Ed. The Chemistry of Carboxylic Acids and Esters, Interscience, London 1969, p. 272.

18. Curtis, D. R., Duggan, A. W., Felix, D. and Johnston, G. A. R. Brain Res. 32 (1971) 69.

19. Johansen, E.S. and Jøns, O. Acta Chem. Scand. A35 (1981) 233.

20. Johansen, E. S. and Jøns, O. Talanta 31 (1984) 743.

21. Honoré, T. and Lauridsen, J. Acta Chem. Scand. B34 (1980) 235.

Received April 15, 1985. 